\title{
Review
}

\section{Private protected areas: management regimes, tenure arrangements and protected area categorization in East Africa}

\author{
Eleanor Carter, William M. Adams and Jon Hutton
}

\begin{abstract}
Private sector bodies can be important owners and managers of conservation areas. However, little is known about the extent, scale and scope of private protected areas. Understanding and defining the characterizations of private protected areas are problematic, as private sector involvement in protected areas can involve an array of different tenure arrangements, management approaches and levels of control. This review examines the challenges of developing protected area categorization beyond the traditional state-led model. We review private protected areas in Kenya and Tanzania, exploring their tenure, the nature of the private sector organizations managing them, and the extent of control exercised within them. Drawing on this we develop a working typology with the aim to encourage further discourse amongst the conservation community on the emerging phenomenon of private protected areas.
\end{abstract}

Keywords Biodiversity conservation, East Africa, land tenure, national parks, private reserves, protected area.

\section{Introduction}

Tn the 2oth century the dominant conservation strategy (in the USA, Western Europe, and in former colonial territories) was the establishment of protected areas through state action (Adams, 2004). However, private nature reserves have long been important in European conservation. In the second half of the 2oth century landholdings by conservation trusts in a number of industrialized countries grew substantially; for example, the Royal Society for the Protection of Birds and the National Trust in the UK, and The Nature Conservancy in the USA (Tunbridge, 1981; Dwyer \& Hodge, 1996). The conservation of biodiversity on private lands was an important element of public policy in many countries, not only in Europe (Kleijn \& Sutherland, 2003; Rafa, 2005) but in the USA (Bernstein \& Mitchell, 2005; Newburn et al., 2005), Aus-

Eleanor Carter (Corresponding author) Environment \& Development Consulting, Cambridge, UK. E-mail carter.ed.consulting@gmail.com

William M. Adams Department of Geography, University of Cambridge, Downing Place, Cambridge, CB2 3EN, UK.

Jon Hutton UNEP-World Conservation Monitoring Centre, 217 Huntingdon Road, Cambridge, CB3 0DL, UK.

Received 30 March 2007. Revision requested 25 July 2007.

Accepted 11 October 2007. tralia (Figgis et al., 2005), and in many developing countries (Langholz \& Lassoie, 2001; Langholz, 2002; Adams, 2004).

A major reason for this was the growth of the global nature-based tourism industry, wildlife-based photo tourism and recreational hunting (Christiansen et al., 2005). Thus in southern Africa a substantial game ranching industry developed on former cattle ranches, based on safari hunting and photo tourism enterprises (Suzuki, 2001; Wels, 2004). Landholding conservation NGOs expanded their operations to developing countries, and wealthy individuals also purchased land to establish private reserves or conservancies (Chudy, 2006).

There is increasing acknowledgement of the importance of the private sector to conservation strategies in the 21st century (Langholz \& Lassoie, 2001; Mitchell, 2005). The Convention on Biological Diversity's programme of work on protected areas comments on the importance of recognizing and promoting 'a broad set of protected area governance types [including] private nature reserves' (CBD, 2006, Prog. Element 2: Specific Goal 2.1) and the Global Environment Facility has committed to developing a private sector strategy (GEF, 2007).

However, there is no definitive definition of a private protected area. A varied terminology exists: terms such as private conservancy, private park, and private reserve are used widely and loosely. In 2003 the World Parks Congress defined private protected areas as land parcels of any size that are predominantly managed for biodiversity conservation, protected with or without formal government recognition and owned or otherwise secured by (1) individuals, (2) communities, (3) corporations, or (4) NGOs (Mitchell, 2005). However, confusingly, these categories of ownership overlap with the four governance categories also adopted by the World Parks Congress (Recommendation V.17): (1) the state, (2) private owners, (3) indigenous and local communities, or (4) protected areas co-managed by groups of stakeholders (Mitchell, 2005).

Koontz (1998) defined private sector operations as 'activities outside the public sector that are independent of government control, usually, but not always, carried on for a profit'. Usher \& Bennett (2003) suggested the wide range of private operators can include individual or family owned businesses, publicly listed companies, organizations with management structures that rely on donations from private entities, corporations or membership subscriptions 
independent of state funds, and organizations with independent management structures that may receive funding from government but have an ability to refuse such funds, and referred to them all as private sector conservation enterprises. Such an enterprise may own and manage a private protected area, or simply manage land owned by another party (e.g. the state). This distinction between ownership and management is critical (Kramer et al., 2002). When the private sector conservation enterprise both owns and manages a private protected area its level of control and freedom of action tends to be much greater. Many private sector conservation enterprises manage land over which they are not owners. For example, in Africa stateowned protected areas are being managed under contract by private companies (e.g. the Mozambican company SRN, which manages the Niassa Reserve in Mozambique), or by foreign not-for profit organizations (e.g. African Parks, which manages the Nechisar National Park, Ethiopia). The creation of contract national parks in South Africa is an example of the reverse process, with the state paying private owners (or communities) so that their land can be incorporated into the management of a neighbouring national park (Magome \& Murombedzi, 2003). In other contexts, private sector conservation enterprises have made alliances with local community partners in developing private protected areas on community held land, where the private operator manages the area and provides the community who own the land with dividends from ecotourism operations.

IUCN currently defines six categories of protected areas based on management objectives (IUCN et al., 1994), and these categories have helped set international standards for accounting and comparisons of protected area systems (Bishop et al., 2004). These do not consider the issue of protected area ownership and governance. The need to extend protected area categorization in this way was debated at a workshop on Governance of Protected Areas in Sub-Saharan Africa (IUCN-CEESP, 2003) and at the Fifth World Parks Congress in 2003 (Bishop et al., 2004; Langholz \& Krug, 2004). The Congress recommended extension of protected area categories to include private protected areas and those managed by local and indigenous communities (Recommendation 19.5 [i]).

Langholz (1996) defined private protected areas as areas $>_{5}$ ha managed to preserve land in an undeveloped state and permitting visitors (see also Langholz \& Lassoie, 2001; Langholz, 2002). However, Langholz's 10 subcategories of private protected areas mix the purposes of the protected areas (hunting, ecotourism, personal retreat) with the identity of their owner. Neither the actual form of tenure (ownership, lease, customary tenure, management agreement) nor the extent of control (the freedom of operation of the managers, such as exercising trespassing laws against non-authorized entrants, through to mixed use, open access areas) are specified.
Here, we propose a definition of a private protected area as an area of land of conservation importance that is directly under the ownership and/or management of a private sector conservation enterprise for the purpose of biodiversity conservation. This purpose may be singular (i.e. the entire mission of the organization is conservation), or it may be concurrent with other objectives (such as a business venture or other social imperative). We define private sector conservation enterprise to include all nonstate bodies or organizations that may be involved in either the management and/or ownership of private protected areas, from corporate institutions and limited companies through to private individuals and trusts. We note that, following Koontz (1998), community groups may in many cases be defined as private sector conservation enterprises, being bodies outside the public sector and independent of government control. Their motives, management mechanisms and rights, and their use of commercial activities (e.g. tourism) to generate income, may be similar to those of private individuals and organizations. This question of community groups as private sector conservation enterprises warrants further attention but is beyond the scope of this study.

In this review we examine the challenges of categorizing private protected areas, drawing on a survey of owners and managers of private protected areas in Kenya and Tanzania. We explore the extent and scale of private protected areas, the forms of tenure under which they are held, the nature of the private sector conservation enterprises managing and/ or owning them, and the range of rights these organizations exercise. Through this review it becomes clear that there are a wide range of diverse approaches in private protected area management and ownership in this region, and the complexities of attempting to contextualize these into a working typology soon become apparent. The aim of this review is to attempt to develop such a typology as a step towards encouraging further discourse on this topic within the international conservation community.

\section{Methods}

We reviewed published and grey literature and contacted a range of institutes and organizations to identify candidate private protected areas in Kenya and Tanzania. We then interviewed private protected area managers and owners, government officials and associated NGO representatives in Kenya and Tanzania during September-November 2005. A snowball approach was used, with each stage of the process analytically triangulated to ensure the body of data was complete and representative (Salganik \& Heckathorn, 2004). The following interviews were undertaken: 20 semistructured interviews with private sector operators (12 in Kenya; eight in Tanzania, many of whom had multiple protected area landholdings or sites under management); 
TABLE 1 The extent of protected areas (PA) and private protected areas (PPA) in Kenya and Tanzania (from our survey, see text for details, and WDPA, 2006).

\begin{tabular}{|c|c|c|}
\hline & Kenya & Tanzania \\
\hline Land area (ha) & $58,037,000$ & $94,509,000$ \\
\hline (i) IUCN Category I-IV PA (ha) ${ }^{1}$ & $3,435,933$ & $4,102,905$ \\
\hline (ii) Forest/Game Reserve (ha) ${ }^{1}$ & $1,071,412$ & $22,358,725$ \\
\hline Total PA (i) + (ii), ha (\% land area) & $4,507,345(7.8 \%)$ & $26,461,630(28.0 \%)$ \\
\hline PPA land gross, ha (\% land area) & $797,068(1.4 \%)$ & $12,565,676(13.3 \%)$ \\
\hline PPA land net, ha (\% land area $)^{2}$ & $797,068(1.4 \%)$ & $8,374,576(8.9 \%)$ \\
\hline
\end{tabular}

${ }^{1}$ From WDPA (2006)

${ }^{2}$ There is a difference between the gross and net values for private protected areas in Tanzania. The gross figures include all those areas that can be defined as private protected areas but some of these areas are already accounted for in (i) and (ii). The net value gives only those areas that are currently not recognized by the WDPA (2006) as protected areas.

25 self-filled questionnaires sent to other operators throughout the region by post, e-mail and fax (18 out of 32 returned in Kenya; seven out of 10 returned in Tanzania); 11 semi-structured interviews with legislators, institutions dealing with land laws, and associated NGOs and conservation organizations in the region.

The questions in both interviews and questionnaires focused on land tenure arrangements, size of private protected area, year of establishment, motivation for establishment, extent of surrounding or integral human communities, relations with neighbours and the state, finance mechanisms, benefit-sharing regimes, and the challenges faced by the enterprise in establishing, owning and/or managing the private protected area. The survey did not capture all private protected areas in Kenya and Tanzania. However, we believe it covered the scope of approaches to private protected area ownership and management in the region.

\section{Extent of private protected areas}

Our survey found that in Kenya private protected areas cover a total area of 797,068 ha, i.e. $1.4 \%$ of the terrestrial land area (Table 1). For comparison, $4.5 \mathrm{~m}$ ha of land is officially gazetted as protected by the state $(8 \%)$. Of this, $3.4 \mathrm{~m}$ ha is managed by the Kenya Wildlife Service, with a further $1.1 \mathrm{~m}$ ha set aside as forest reserves or similar designations under state management through local authorities (WDPA, 2006).

In Tanzania the WDPA database (2006) indicates a much larger area of conservation land under some form of state management $(26.5 \mathrm{~m} \mathrm{ha,} 28 \%$ of the terrestrial land area). Of this, $4.1 \mathrm{~m}$ ha is officially gazetted as having protected area status under state management (through Tanzania National Parks), with a further $22.4 \mathrm{~m}$ ha set aside as Game Reserves and Forest Reserves under state management through local authorities, the Division of Wildlife, and the Forestry and Bee-Keeping Division. In Tanzania $12.6 \mathrm{~m}$ ha of land has private protected area status according to our definition (13.3\% of all land in Tanzania;
Table 1). However, $4.2 \mathrm{~m}$ ha of this represents hunting concessions within Game Reserves, and is already counted in the state protected area statistics; $c$. $80 \%$ of Tanzanian private protected area land is hunting concession.

Individual private protected areas in Kenya and Tanzania vary in size (Fig. 1). Most are 10,001-25,000 ha but private protected areas in Tanzania are larger, with $51 \%$ of such areas being $>200,000$ ha, reflecting the size of hunting blocks. Landholding by private sector conservation enterprises started in 1971 in Kenya and 1982 in Tanzania but in both countries the number of private protected areas increased rapidly in the mid to late 1990s, reflecting a growing interest in proactive conservation management from private sector operators in Kenya, and demands from clients and the public, and changes in hunting legislation that demanded operators engage in conservation activities in Tanzania.

\section{Tenure regimes}

Kenya

In Kenya $25 \%$ of private protected areas are under longterm private ownership (e.g. the Lewa Conservancy), a further $38 \%$ are under group-ranch ownership (such as the Shompole Project), and $16 \%$ are on land actually owned by the state (but managed by private sector conservation enterprises), such as the Mara Conservancy (Table 2). Eighteen per cent of private protected areas are leased directly by private sector conservation enterprises (e.g. Rukinga Wildlife Sanctuary and Ol Lentille Sanctuary), with lease durations of 10-500 years. Some private protected areas are on rented land (3\%), with an arrangement between local land owners and a private sector conservation enterprise, such as the Campfire Conservation Project at Koiyaki-Lemek group ranches. Land tenure laws in Kenya are complex. The Registered Lands Act of 1963 (in combination with the Transfer of Property Act) governs individual ownership of land, although numerous other Acts and policy documents refer to various tenure arrangements currently possible under Kenyan law. 


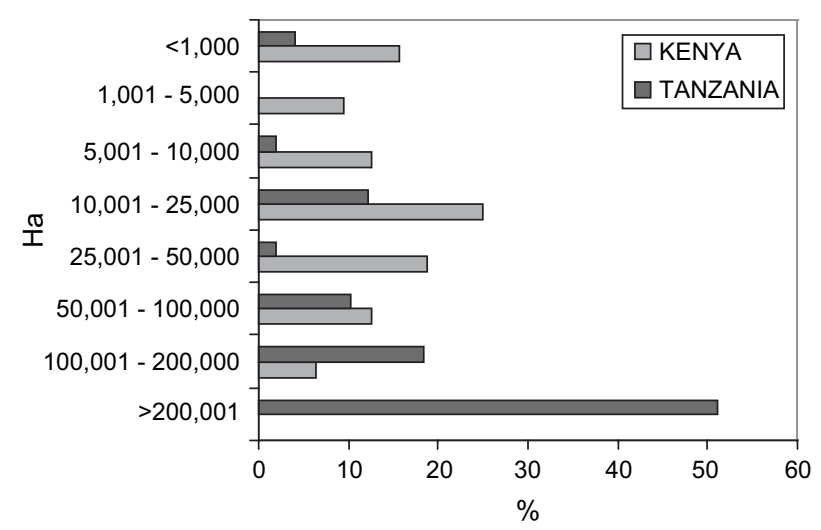

FIG. 1 The sizes of individual private protected areas in Kenya and Tanzania.

\section{Private protected areas on group ranches}

The commonest Kenyan private protected areas are on group ranches (38\%, Table 2). More than 400 group ranches are registered (or are in the process of registration), under the Land (Group Representatives) Act 1968. Group ranches are defined as 'demarcated area[s] of rangeland to which a group of pastoralists, who graze their individually owned herds on it, have official land rights' (KameriMbote, 2005). Group is defined as 'a tribe, clan, section, family or other group of persons, whose land under recognized customary law belongs communally to the persons who are for the time being the members of the group' (Land Adjudication Act [rev.1977], CAP.284, p.5).

Group ranches face various problems, including: population growth and dispute over appropriate land use; poor governance, with disputes over boundaries and dispossession because of default on payments to finance institutions where the land has been used as collateral (Mironga, 2004); government policy that favours individual (rather than group) tenure and agriculture (rather than pastoralism), leading to land speculation, group ranch subdivision and sale (Kameri-Mbote, 2005). These factors have led to the subdivision of many group ranches under individual title deeds (Woodhouse, 2003). Such subdivision has led to loss of wildlife migratory routes, diminished dispersal areas and increased human/wildlife conflict (Wayumba, 2004).

The emergence of private protected areas on these lands has been driven by agreements between ecotourism operators (as private sector conservation enterprises) and group ranches (as owners of the land) and usually involve the group setting aside land as a private protected area in return for a share of the tourist revenue and other benefits (e.g. employment). Examples of such operations are the Shompole and Il Ngwesi group ranches. Early promoters of group ranch private protected areas were predominantly expatriate entrepreneurs $(58 \%$ of private protected areas in this category). However, this mode of operation has also proven attractive to group ranch members themselves, and $42 \%$ of private protected areas have involved group ranches actively seeking private sector partners. Some subdivided group ranches are considering regrouping their lands through arrangement with private sector conservation enterprise operators. For example, Koiyaki-Lemek Group Ranch on the border of the Maasai Mara is working with Campfire Conservation Ltd to turn a large area that has already been subdivided into 1,006 plots (with 1,006 different title deed holders) into a conservation area, with all the owners renting their areas to the conservancy in exchange for a share of the tourism revenues. This suggests there is a potential for private protected area development to reverse the trend of group ranch subdivision (and its consequential impact on biodiversity).

\section{Private protected areas on land owned by private individuals}

In Kenya $25 \%$ of private protected areas are held under long-term individual ownership. European colonial settlers obtained freehold tenure of farms and ranches giving 'absolute ownership of that land together with all rights, and privileges relating thereto' (Mironga, 2004). After Kenyan independence such land was transferred to longterm leasehold of 999 years. In recent years some private ranch owners have created private protected areas (often called conservancies), usually with an ecotourism venture to generate revenue. These private protected areas are predominantly held by descendents of European settlers. Respondents viewed conservation as a sustainable longterm management option for their land. The only alternative for uneconomic cattle ranches would be subdivision and sale, as for group ranches. Under the draft Kenyan constitution (2005: Section 83 [1] and [2]) the length of leases will probably be reduced from 999 to 99 years to bring them in line with other leased areas in Kenya. This could have repercussions for the future sustainability of these private protected areas, especially in the light of experiences in Zimbabwe (Wolmer, 2005). However, in our survey individual owners expressed no explicit fear of a challenge to their rights as landholders.

\section{Other private protected areas}

Of the remaining private protected areas, $16 \%$ are under state ownership in areas such as Trust Lands, which are decreed under the Trust Land Act (Cap288) of 1939 (Table 2). The local county council holds the land for the benefit of the persons ordinarily resident on the land [for] public purposes or for such other purposes as the county council may think is beneficial' (Wayumba, 2004). These areas were not taken for European settlement during the colonial period nor subsequently consolidated or registered in a group or individual's name (Kameri-Mbote, 2005).

Examples of this kind of private protected area include the Ngare Ndare Forest Trust in Laikipia and the Mara Triangle (the north-western portion of the Maasai Mara). This latter area is held in trust by the Transmara County 
TABle 2 Payment type and tenure arrangements for private protected areas (PPA) in Kenya and Tanzania, with percentage in each category.

\begin{tabular}{|c|c|c|c|}
\hline Payment type & Tenure arrangement & $\begin{array}{l}\text { PPA } \\
\text { Kenya (\%) }\end{array}$ & $\begin{array}{l}\text { PPA } \\
\text { Tanzania (\%) }\end{array}$ \\
\hline \multirow[t]{4}{*}{ No yearly fee } & State owned & 16 & 2 \\
\hline & Long-term individual ownership ( $>500 \mathrm{yr}$ ) & 25 & 0 \\
\hline & Group ranch customary tenure $(>500 \mathrm{yr})$ & 38 & 0 \\
\hline & Total & 79 & 2 \\
\hline \multirow[t]{7}{*}{ Yearly, or overall payment to Department of Lands } & Leased from state $101-500 \mathrm{yr}$ & 3 & 0 \\
\hline & Leased from state $51-100 \mathrm{yr}$ & 12 & 6 \\
\hline & Leased from state $36-50 \mathrm{yr}$ & 0 & 0 \\
\hline & Leased from state $10-35 \mathrm{yr}$ & 3 & 4 \\
\hline & Leased from state $<10 \mathrm{yr}$ & 0 & 0 \\
\hline & Land is under a rental agreement & 3 & 0 \\
\hline & Total & 21 & 10 \\
\hline Yearly payment to Department of Wildlife & Leased Hunting Block & NA & 78 \\
\hline Informal payment to local villages & Informal rental agreement & 0 & 10 \\
\hline
\end{tabular}

Council, which has an agreement with the Mara Conservancy, an NGO. This conservancy, in cooperation with Earthview Ltd, has exclusive management rights over the area in exchange for ensuring the Council receives the appropriate portions of revenue from the conservancy gate fees and other ecotourism operations in the region. The NGO also ensures that revenue sharing takes place with nearby communities (in group ranches that have not subdivided) and manages anti-poaching activities in the area on behalf of the Council.

The remaining Kenyan private protected areas (21\%, Table 2) are leased directly from the Kenya Department of Lands for a fixed yearly rent, or overall fee or rental, for a set duration at a set rate (negotiable and subject to various considerations such as location, size of area, and infrastructure). An example is Rukinga Wildlife Sanctuary, which is on the site of the old Galana Ranch and has now been bought by an American company, Wildlife Works Ltd. They run it as a private wildlife sanctuary with revenue coming from a 'discovery centre' and research post on site, and an eco-factory sourcing and making local products for export.

\section{Tanzania}

In Tanzania all land is ultimately owned by the state, and may only be leased by companies for set periods of time, no longer than 99 years. Foreign owned companies must lease land through the Tanzania Investment Commission on the mainland, and through the Zanzibar Investment Promotion Agency on Zanzibar.

Private protected areas in leased hunting blocks Our survey showed that the most common form of tenure for private protected areas is through hunting blocks leased from the government ( $78 \%$, Table 2), with 122 hunting blocks, regulated through the Wildlife Conservation Act of
1974 and the 2000 Tourism Hunting Regulations. Hunting companies can lease these blocks for 5 years, during which time the Department of Wildlife sets a hunting quota. The Tourism Hunting Regulations require hunting companies to: have a community development component to their operations (i.e. there must be some sort of alliance with nearby communities providing tangible community development assistance); conduct anti-poaching activities independent of state assistance (i.e. hunting companies must be responsible for safeguarding wildlife against illegal offtake); develop the block's infrastructure (e.g. provision of roads, boundary maintenance where needed and appropriate, conduct research).

Hunting blocks are in Game Reserves, Game Controlled Areas, Wildlife Management Areas, and Open Areas, which have different utilization and access rights. In Game Reserves local people do not have the legal right to occupy or have access, no vegetation cutting or tree felling is permitted without a government licence, and hunting, grazing of livestock, and cultivation are not permitted. In Game Controlled Areas there can be villages (but not urban areas), inhabitants can farm and graze their livestock, and hunt if they obtain a licence from the government (although the quota for any professional tourism hunting operation will be considered when deciding whether to issue a permit to a local person).

In Wildlife Management Areas accredited village associations can gain management rights over an area and receive quotas for wildlife utilization. By the start of 2006 only two such Areas existed, although more are in the process of being created. Many of these, however, have yet to be formally registered under the Wildlife Act 2002. In such cases the village associations themselves may be regarded as private sector conservation enterprises, although they may choose to form an agreement with another, separate private sector conservation enterprise, such as a hunting company, to work and manage such 
TABLE 3 The range of management regimes in private protected areas (PPA) in Kenya and Tanzania, with percentages and examples of each type.

\begin{tabular}{|c|c|c|c|c|}
\hline & Management & $\begin{array}{l}\text { PPA } \\
\text { Kenya } \\
(\%)\end{array}$ & $\begin{array}{l}\text { PPA } \\
\text { Tanzania } \\
(\%)\end{array}$ & Examples \\
\hline \multirow[t]{4}{*}{$\begin{array}{l}\text { Sole management: } \\
\text { private sector } \\
\text { conservation } \\
\text { enterprise management } \\
\text { agents operating } \\
\text { independently }\end{array}$} & $\begin{array}{l}\text { Nationally registered } \\
\text { ltd companies }\end{array}$ & 22 & 12 & $\begin{array}{l}\text { Kenya Oryx Ltd (managing Loisaba Private } \\
\text { Wildlife Conservancy); Kisima } \\
\text { project in Rumuritu \& Athi River Ranch } \\
\text { Tanzania Lukwati Game Reserve; } \\
\text { concessions under African } \\
\text { Bush Hunting Company }\end{array}$ \\
\hline & Private individuals & 13 & 2 & $\begin{array}{l}\text { Kenya Borana Game Sanctuary; Ol Malo Project } \\
\text { Tanzania A private wealthy individual } \\
\text { (Grumeti Reserves) }\end{array}$ \\
\hline & $\begin{array}{l}\text { Registered community } \\
\text { organizations }\end{array}$ & 9 & 0 & $\begin{array}{l}\text { Kenya Tungai Conservancy \& Kalama Community } \\
\text { Conservation; project on Gir Gir ranch }\end{array}$ \\
\hline & Other sole management & 19 & 2 & $\begin{array}{l}\text { Kenya Overseas registered ltd } \\
\text { companies (e.g. Rukinga Wildlife } \\
\text { Sanctuary); overseas-based NGOs } \\
\text { (e.g. Ol Pejeta Conservancy); } \\
\text { nationally-based NGOs (e.g. Kipini } \\
\text { Wildlife \& Botanical Conservancy) } \\
\text { Tanzania A nationally registered } \\
\text { ltd company (CCAfrica, Mnemba Island) }\end{array}$ \\
\hline \multirow{5}{*}{$\begin{array}{l}\text { Joint management: } \\
\text { private sector } \\
\text { conservation enterprise } \\
\text { management agents } \\
\text { operating through } \\
\text { collaborative/ } \\
\text { joint arrangements }\end{array}$} & $\begin{array}{l}\text { Joint collaborations between } \\
\text { nationally registered ltd } \\
\text { companies \& registered } \\
\text { community organizations }\end{array}$ & 22 & 0 & $\begin{array}{l}\text { Kenya Lekurruki Group Ranch \& Tassia Lodge; } \\
\text { Namyunak Conservancy \& Sarara Lodge; } \\
\text { Shompole Project \& Art of Ventures }\end{array}$ \\
\hline & $\begin{array}{l}\text { Joint collaborations between } \\
\text { a nationally registered ltd } \\
\text { company \& nationally } \\
\text { based NGO }\end{array}$ & 0 & 47 & $\begin{array}{l}\text { Tanzania Luganzo Game Controlled Area } \\
\text { managed between Robin Hurt Safaris Ltd \& } \\
\text { Cullman \& Hurt Community Wildlife NGO }\end{array}$ \\
\hline & $\begin{array}{l}\text { Joint collaborations between } \\
\text { overseas registered ltd } \\
\text { company \& nationally } \\
\text { based NGO }\end{array}$ & 0 & 23 & $\begin{array}{l}\text { Tanzania Maswa Game Reserve managed } \\
\text { between Tanzania Game Trackers } \\
\text { Safaris Ltd \& Friedkin Conservation } \\
\text { Fund NGO }\end{array}$ \\
\hline & $\begin{array}{l}\text { Joint collaborations between } \\
\text { nationally registered ltd } \\
\text { companies \& non-registered } \\
\text { community organizations }\end{array}$ & 6 & 10 & $\begin{array}{l}\text { Tanzania Areas in the Yaeda Valley managed } \\
\text { between Dorobo Safaris Ltd \& the village council }\end{array}$ \\
\hline & Other joint management & 9 & 4 & $\begin{array}{l}\text { Kenya Nationally registered ltd companies \& } \\
\text { non-registered community organizations (Cottars } \\
\text { 1920s camp \& local village group; Campfire } \\
\text { Conservation Ltd + cross-sections of Koiyaki \& } \\
\text { Lemek Group Ranches); overseas registered } \\
\text { ltd company \& a non-registered community } \\
\text { organization (e.g. the Himili Morowa Hotel + } \\
\text { Mulikani \& Mtotana CBOs in Ozi); } \\
\text { nationally registered NGO \& a local } \\
\text { authority (e.g. The Mara Conservancy); } \\
\text { registered local community organization \& } \\
\text { local authority (e.g. the Naibunga Trust) } \\
\text { Tanzania An overseas registered company \& a } \\
\text { local authority state body (CCAfrica's sites on } \\
\text { Klein's Camp \& Mnemba Island + the } \\
\text { associated state body) }\end{array}$ \\
\hline
\end{tabular}


areas. Whilst these collaborative arrangements can be made, the village associations cannot sublease the area to another private sector conservation enterprise (such as a company). Thus, any agreements are relatively informal between the village concerned and the private company.

Hunting blocks in Open Areas are freely accessible to local people, who may also hunt in the area if they obtain a licence from the government. Regulations over utilization are more relaxed in these areas than in Game Controlled Areas.

Hunting companies take different approaches to their responsibilities under the Tourism Hunting Regulations. Some are far more effective than others. For example, The Cullman and Hurt Community Wildlife Project charge their clients a $20 \%$ community fee additional to the game fee, which is then divided between neighbouring communities for pre-approved programmes. Additionally, they independently hire game scouts from within the communities to patrol the area and safeguard wildlife. However, not all hunting operators have conservation as a top priority, and the figures and information presented here represent only those hunting companies who have proactively shown that biodiversity conservation is a primary mission of their organization's existence, and in these instances the land under their management may be regarded as a private protected area.

\section{Private protected areas on other land leased from the}

Government

Ten per cent of the remaining Tanzanian private protected areas are leased formally from the Government Department of Lands for a fixed yearly fee in the same way that any regular business operation leases land (Table 2). In Klein's Camp, the operator (CCAfrica), has a concession from the government to manage the area whilst the tenancy remains with the state. In the Chumbe Island Marine Protected Area, land of conservation value (forest reserve and coral reef sanctuary) is managed by a private company (CHICOP) through contract with the state, whilst the area within the private protected area that is utilized for ecotourism activities is being leased directly by the Company.

Private protected areas on rented land

In $10 \%$ of cases private protected areas have been created through an informal arrangement whereby a local community rents their land to a private sector conservation enterprise on a yearly basis for a set fee (Table 2). This relatively informal arrangement can be attractive to private sector conservation enterprises as they obtain exclusive tourism access and management influence over particularly important sites held by local communities and not available for lease from the government. This also avoids the restrictive, and often expensive, government mechanisms surrounding legal leasing arrangements, where fees are often set arbitrarily. The requirement for 'proof of financial profit' for any limited company wishing to become established in Tanzania also limits the flexibility of private sector conservation enterprise agents to invest in unprofitable biodiversity conservation and local community work.

\section{Management regimes and rights}

Our survey has shown that private sector conservation enterprises managing private protected areas can have a range of different rights over the utilization of the land under their management (Table 3). Their freedom of operation and their rights in any given area are often related to the land tenure arrangements and/or the agreement established with the state or the local community concerned. Some private sector conservation enterprises have sole management rights over an area. These include nationally registered limited companies, private individuals, and registered community organizations. Other private protected areas are subject to joint management arrangements: collaborations between nationally registered limited companies and registered community organizations or nationally based NGOs, between overseas registered limited companies and nationally based NGOs, and between nationally registered limited companies and non-registered community organizations.

We define the three levels of management rights of private sector conservation enterprises recorded in our survey as low, medium and high:

Level 1, low The right to control development and the shared rights to generate revenue from the land. This allows the private sector conservation enterprise the right to manage how the land is used, including decisions concerning infrastructure development. However, this does not include the right to limit access to the land by other individuals, or the right to preclude others from undertaking revenue generating operations on the land (such as ranching of cattle or handicraft sales to tourists), although it does allow the private sector conservation enterprise the right to direct and control where on the land any such activities may be conducted, and enable particular conservation/species-based set-asides.

Level 2, medium This includes all of the development rights of Level 1 plus the exclusive rights to generate revenue from the land. The private sector conservation enterprise has the right to control all revenue generating operations on the land and prevent others from attempting to engage in any revenue generating operations (such as curio trading or cattle grazing).

Level 3, high This level includes all of the rights of Levels 1 and 2 plus the right to control access to the area (and deny access, excluding others from entering an area under the trespass laws). This enables a management regime most similar to a traditional state managed protected area. 
TABLE 4 A typology for private protected area (PA) categorization (see text for details).

\begin{tabular}{|c|c|c|c|c|}
\hline Category & Landholder & $\begin{array}{l}\text { Management } \\
\text { organization }\end{array}$ & $\begin{array}{l}\text { Relationship of management } \\
\text { organization to landholder }\end{array}$ & Name \\
\hline$\overline{1 \mathrm{a}}$ & Individual (ownership or lease) & Individual & Same: management agent as landholder & $\begin{array}{l}\text { Individual } \\
\text { Private PA }\end{array}$ \\
\hline $1 b$ & Individual (ownership or lease) & Individual & Operator different from landholder & Private PA \\
\hline 2 & $\begin{array}{l}\text { Business corporation } \\
\text { (ownership or lease) }\end{array}$ & Business corporation & Same: operator is landholder & $\begin{array}{l}\text { Private } \\
\text { Corporate PA }\end{array}$ \\
\hline $2 b$ & $\begin{array}{l}\text { Business corporation } \\
\text { (ownership or lease) }\end{array}$ & Business corporation & Operator different from landholder & Corporate PA \\
\hline 3 & $\begin{array}{l}\text { Conservation trust } \\
\text { (ownership or lease) }\end{array}$ & Conservation trust & Same: operator is landholder & $\begin{array}{l}\text { Conservation } \\
\text { Trust PA }\end{array}$ \\
\hline $4 \mathrm{a}$ & $\begin{array}{l}\text { Community or community trust } \\
\text { (ownership, trust or lease) }\end{array}$ & Community & Same: operator is landholder & $\begin{array}{l}\text { Community } \\
\text { Controlled PA }\end{array}$ \\
\hline $4 \mathrm{~b}$ & $\begin{array}{l}\text { Community or community trust } \\
\text { (ownership, trust or lease) }\end{array}$ & $\begin{array}{l}\text { Individual, business } \\
\text { corporation, } \\
\text { conservation trust }\end{array}$ & $\begin{array}{l}\text { Leasehold, joint tenure with owners, } \\
\text { management agreement, concession }\end{array}$ & $\begin{array}{l}\text { Joint Private- } \\
\text { Community PA }\end{array}$ \\
\hline $4 \mathrm{c}$ & $\begin{array}{l}\text { Community or community trust } \\
\text { (ownership, trust or lease) }\end{array}$ & $\begin{array}{l}\text { Community or } \\
\text { community } \\
\text { owned business }\end{array}$ & Leasehold or management agreement & Community PA \\
\hline $5 \mathrm{a}$ & State & $\begin{array}{l}\text { Individual, business } \\
\text { corporation, } \\
\text { conservation trust }\end{array}$ & $\begin{array}{l}\text { Leasehold, joint tenure with state, } \\
\text { management agreement, concession }\end{array}$ & $\begin{array}{l}\text { Conservation } \\
\text { Concession }\end{array}$ \\
\hline $5 b$ & State & $\begin{array}{l}\text { Community or } \\
\text { community } \\
\text { owned business }\end{array}$ & $\begin{array}{l}\text { Leasehold, joint tenure with owners, } \\
\text { management agreement, concession }\end{array}$ & $\begin{array}{l}\text { Community } \\
\text { Conservation } \\
\text { Concession }\end{array}$ \\
\hline
\end{tabular}

Nearly all managers of private protected areas in Kenya $(84 \%)$ had Level 3 rights. These managers can prohibit entry under Kenyan trespass laws just as the Kenya Wildlife Service can control entry in strict state protected areas. Of the remaining Kenyan private sector conservation enterprises, $10 \%$ have Level 2 rights over both development and revenue generating options but not over access, and only $6 \%$ had Level 1 rights over issues of development alone. All of the operations experiencing these low-level rights were private protected areas managed through joint collaborations between limited companies and local community bodies.

In Tanzania $80 \%$ of the non-hunting private protected areas also have Level 3 rights over the regulation of entry to the area, much in the same way as a state park may control access. In $41 \%$ of private protected hunting areas the private sector conservation enterprises also have Level 3 rights, and these are predominantly in hunting blocks based in legally recognized Game Reserves. In the remaining private protected areas the private sector conservation enterprises have only Level 1 rights over development in their area, meaning that cattle grazing and agriculture may take place.

\section{Discussion}

This survey of the owners and operators of private protected areas in Kenya and Tanzania reveals that a complex mix of state, civil society and private sector organizations are involved in the management and governance of private protected areas. The range of possible interactions and collaborations between state, private and communal bodies (and even tri-sector partnerships between all three) is potentially bewildering.

These case studies are merely a snapshot of the growing phenomenon of private protected areas globally. Little is known about the scale and scope of private protected area growth internationally, the efficacy of private protected areas in meeting biodiversity imperatives, and the associated social impacts of such initiatives. It is critical to address this lack of knowledge to enable government decision makers to construct appropriate legal frameworks to ensure private conservation practices are implemented appropriately, supported politically, and managed in such a way as to meet vital concurrent social imperatives. Our study confirms the observation of Langholz (2002) that 'as private reserves continue their quiet proliferation ... we desperately need to characterize this growing phenomenon and ascertain its potential contribution to biodiversity conservation'.

In response to the call to categorize private protected areas (WPC, 2003, recommendation 5.19), the complexity of institutional arrangements observed in this survey has significant implications. The existing IUCN categories for protected areas (IUCN et al., 1994) are insufficient to express these complexities adequately. Some of the hunting concessions in Tanzania would currently qualify under IUCN criteria as category VI protected areas ('Managed Resource Protected Area: a protected area managed mainly for the sustainable use of natural ecosystems'; IUCN et al., 
1994). However, the extent to which management effectively promotes conservation varies.

Effective private protected area categorization will need to consider two dimensions: the nature of the landholder (individual, business corporation, community organization) and the nature of the management organization (private company, corporation, private individual, community group or joint company/community organization). We offer a typology based on these factors (Table 4). The 10 categories capture important dimensions of the complexity of private protected areas in Kenya and Tanzania but are preliminary, and offered as a basis for debate, refinement and adaptation to other contexts.

The typology does not take account of the management purpose of the private protected area (the extent to which the explicit purpose of the area matches any given criteria of the objectives of conservation) or the management effectiveness of the private protected area (the extent to which a private protected area achieves its specified aims). Additionally, the titles given to the range of private protected areas in the typology do not indicate the level of control (management rights of Levels 1-3 described above) that the management organization has over the private protected area.

To include all of these additional concerns into a typology would require a third dimension, and be too complex to be a useful contribution to the purposes of providing international frameworks for protected area systems (Bishop et al., 2004). However, once the challenges of categorizing private protected areas are addressed, it is these questions of how private protected areas are managed, how effective they are in meeting both conservation goals and concurrent social imperatives of protected area management, the possible role of the international conservation community in private protected areas, and the political ramifications and potential for sustainability that should be the focus of discourse concerning private protected areas.

\section{Acknowledgements}

This review derives from a study commissioned to examine private sector conservation enterprises in East Africa (E. Carter, 2005, Private Sector Conservation Enterprise in East Africa: Scale, Scope \& Sustainability, Unpublished Report, Fauna \& Flora International \& ResourceAfrica). The contents represent the authors' own views and do not necessarily reflect the views or policies of UNEP or associated organizations. We would like to thank all those who took part in the survey.

\section{References}

Adams, W.M. (2004) Against Extinction: The Story of Conservation. Earthscan, London, UK.
Bernstein, J. \& Mitchell, B. (2005) Land Trusts, private reserves and conservation easements in the United States. Parks, $15,48-60$.

Bishop, K., Dudley, N., Phillips, A. \& Stolton, S. (2004) Uses and Performance of the IUCN System of Management Categories for Protected Areas: Speaking a Common Language. Cardiff University, IUCN \& UNEP-WCMC, Gland, Switzerland.

CBD (Convention on Biological Diversity) (2006) Http:// www.cbd.int/protected/pow.shtml?prog=p2 [accessed 6 February 2008].

Christiansen, J., Hall, R., Chandler, H., Torfs, M., Zogbi, M., Lovera, S. et al. (2005) Nature for Sale: The Impacts of Privatizing Water and Diversity. Friends of the Earth International, Amsterdam, The Netherlands.

Chudy, J. (2006) Green barons. Portfolio (Emirate Airlines), August/ September, 45-46.

Dwyer, J. \& Hodge, I. (1996) Countryside in Trust: Land Management by Conservation, Amenity and Recreation Organizations. John Wiley and Sons, Chichester, UK.

Figgis, P., Humann, D. \& Looker, M. (2005) Conservation on private land in Australia. Parks, 15, 19-29.

GEF (Global Environment Facility) (2007) Revised Policy Recommendations: Chair's Proposal (GEF/R.4/23/Rev.1). GEF, Washington, DC, USA.

IUCN-CEESP (2003) La Kompienga declaration on governance of Africa's protected areas: Community Empowerment for Conservation. Policy Matters, 12, 105-108.

IUCN, CNPPA \& WCMC (1994) Guidelines for Protected Area Management Categories. IUCN/CNPPA/WCMC, Gland, Switzerland.

Kameri-Mвоте, P. (2005) Land Tenure, Land Use and Sustainability in Kenya: Towards Innovative Use of Property Rights in Wildlife Management. Working Paper, International Environmental Law Research Centre, Nairobi, Kenya.

Kleijn, D. \& Sutherland, W.J. (2003) How effective are European agri-environment schemes in conserving and promoting biodiversity? Journal of Applied Ecology, 4, 947-969.

Koontz, C.M. (1998) Glossary of Marketing Definitions. International Federation of Library Associations \& Institutions, The Hague, The Netherlands. Http://www.ifla.org/VII/s34/pubs/ glossary.htm [accessed 25 January 2008].

Kramer, R., Langholz, J. \& Salafsky, N. (2002) The role of the private sector in protected area establishment and management. In Making Parks Work: Strategies for Preserving Tropical Forests (eds J. Terborgh, C. van Schaik, L. Davenport \& M. Rao), pp. 335-351. Island Press, Chicago, USA.

LANGHOLZ, J. (1996) Economics, objectives, and success of private nature reserves in sub-Saharan Africa and Latin America. Conservation Biology, 10, 271-280.

Langholz, J. (2002) Privately owned Parks. In Making Parks Work: Strategies for Preserving Tropical Forests (eds J. Terborgh, C. van Schaik, L. Davenport \& M. Rao), pp. 172-188. Island Press, Chicago, USA.

LANGHOLZ, J. \& KRUG, W. (2004) New forms of biodiversity governance: non-state actors and the private protected area plan. Journal of International Wildife Law \& Policy, 7, 1-21.

Langholz, J. \& Lassoie, J.R. (2001) Perils and promise of privately owned protected areas. BioScience, 51, 1079-1085.

Magome, H. \& Murombedzi, J. (2003) Sharing South African national parks: community land and conservation in a democratic South Africa. In Decolonizing Nature: Strategies for Conservation in a Post-colonial Era (eds W.M. Adams \& M. Mulligan), pp. 108-134. Earthscan, London, UK. 
Mironga, J.M. (2004) The implications of existing land tenure systems on land use and natural resource management in Kenya. Ossrea Bulletin, Vol. I(2). Http://www.ossrea.net/publications/ newsletter/juno4/farticle17.htm [accessed 25 January 2008].

Mitchell, B. (2005) Editorial. Parks, 15, 1-5.

Newburn, D., Reed, S., Berck, P. \& Merenlender, A. (2005) Economics and land-use change in prioritizing private land conservation. Conservation Biology, 19, 1411-1420.

RafA, M. (2005) Protecting nature and landscape in southern Europe: a social approach. Parks, 15, 61-66.

Salganik, M.J. \& Heckathorn, D.D. (2004) Sampling and estimation in hidden populations using respondent-driven sampling. Sociological Methodology, 34, 193-239.

SUZUKI, Y. (2001) Drifting rhinos and fluid properties: the turn to wildlife production in western Zimbabwe. Journal of Agrarian Change, 1, 600-625.

TUNBRIDGE, J.E. (1981) Conservation trusts as geographical agents: their impact upon landscape, townscape and land use. Transactions of the Institute of British Geographers, 6, 103-125.

Usher, G.A. \& Bennett, J.W. (2003) Defining Private Sector Conservation Enterprises in Australia. Research Note 2, Rural Industries Research and Development Corporation, Canberra, Australia.

Wayumba, G. (2004) A Review of Special Land Tenure Issues in Kenya. Paper presented at the Expert Group Meeting on Secure Land Tenure: Non-legal Frameworks and Tolls, FIG Commission 7, ISK, UN-HABITAT \& CASLE, Nairobi, Kenya.

WDPA (2006) World Database on Protected Areas. Http://www. unep-wcmc.org/wdpa/ [accessed 6 February 2008].

Wels, H. (2004) Private Wildlife Conservation in Zimbabwe: Joint Ventures and Reciprocity. Afrika-Studiecentrum series, Vol. 2, Brill, Leiden, The Netherlands.
Woodhouse, P. (2003) African enclosures: a default mode of development. World Development, 31, 1705-1720.

Wolmer, W. (2005) Wilderness gained, wilderness lost: wildlife management and land occupations in Zimbabwe's southeast lowveld. Journal of Historical Geography, 31, $260-280$.

WPC (2003) World Parks Congress, Recommendation 5.19 IUCN Protected Area Management Categories. Http://www.iucn.org/ themes/wcpa/wpc2003/pdfs/outputs/recommendations/approved/ english/html/r19.htm [accessed 7 February 2008].

\section{Biographical sketches}

Eleanor Carter specializes in biodiversity conservation management. Her research interests include protected area and coastal zone management and strategy development, the convergence of conservation and development agendas, and the challenges associated with putting policy into practice. She spent 6 years as the manager of a private protected area in East Africa, and has worked for international NGOs, governmental and inter-governmental institutions in Africa, Asia and the Pacific. BILl Adams has worked for many years on the problem of unsustainable development and the management of water and living resources. He has a particular interest in the history of conservation and the development of conservation strategies that take account of human needs. Jon HutTon has conducted research on the sustainable use of biodiversity and the way that rural communities craft livelihood strategies from the use of living natural resources. He is Chair of the IUCN/SSC Sustainable Use Specialist Group and Vice-Chair of the Crocodile Specialist Group. 